\title{
THE EPIDEMIC OF JUSTINIAN (AD 542): A PRELUDE TO THE MIDDLE AGES
}

\begin{abstract}
The epidemic that struck Constantinople and the surrounding countries during the reign of Justinian in the middle of the $6^{\text {th }}$ century, was the first documented pandemic in history. It marked the beginning of plague as a nosological problem that would afflict the world until the $21^{\text {st }}$ century. The symptoms of the disease, as described by various contemporary writers (especially the historian and confidant of the emperor, Procopius, and the two church historians, John of Ephesus and Euagrius), are discussed. There is little doubt that the disease was the plague. The most common form in which it manifested was bubonic plague, which is spread by infected fleas and is not directly contagious from patient to patient. There is also evidence of septicaemic plague and possibly even pneumonic plague. The disastrous effects of the plague were described vividly by contemporary writers. A major problem was to find ways to dispose of infected corpses. It is estimated that about one third of the population died - a figure comparable to the death rate during the Black Death in the Middle Ages. Famine and inflation, the depopulation of the countryside, and a critical manpower shortage in the army were further effects which all contributed to bringing to a premature end Justinian's attempt to restore the grandeur of the Roman empire, and precipitating the advent of the Middle Ages.
\end{abstract}

\section{INTRODUCTION}

The epidemic which devastated Constantinople in the $6^{\text {th }}$ century during the reign of Justinian formed part of the first genuine pandemic in history to be documented. It also ushered in a new global health problem - the plague (infection by Yersinia pestis), a disease which would afflict the international community for almost 1300 years thereafter, causing among other cataclysms the medieval "Black Death" (13461361). In fact, the word "plague" came to be popularly considered synonymous with serious epidemic disease, whatever its cause. 
The epidemic of Justinian (542 AD)

\section{THE PERIOD AND THE SOURCES}

Justinian I (482-565 AD), who ruled the Eastern Roman Empire (Byzantium) from AD 527 to 565, a century after the fall of Rome and the Western Roman Empire, was the most able of the Byzantine emperors. Supported by his dynamic wife, Theodora, and two outstanding generals (Narses and Belisarius), he succeeded in briefly rekindling the glory of the ancient Roman Empire. He also made a lasting contribution to the law by codifying the existing Roman legal principles in his Corpus Juris Civilis, which would continue to influence the practice of law even into modern times.

The historian of the Justinian epidemic, Procopius (AD 499-565), experienced it at first hand. As a confidant of Justinian (although eventually estranged) and an adviser to Belisarius, Procopius travelled widely and had access to all information relevant to his historiography. Contemporaries such as Bishop John of Ephesus and Euagrius Scholasticus also described the epidemic and its aftermath, while others such as Johannes Malalas, the monk Theophanes, Agathias of Myrina and Gregory of Tours made minor contributions.

The early $6^{\text {th }}$ century was marked by a plethora of natural disasters such as earthquakes (for instance that which occurred in Antioch in AD 526, claiming almost a quarter of a million victims), famine, floods, and a series of minor epidemics, ${ }^{1}$ as well as volcanic eruptions (of which Vesuvius in 513 proved the most dramatic). It was against this background that the catastrophic epidemic broke out in the Middle East.

1 John of Ephesus, Commentary fragm. II. F p. 232 lines 18-21; cf. also Procopius, History of the wars II.14.6, on an earthquake in Antioch in AD 526 which claimed about 300000 lives. 


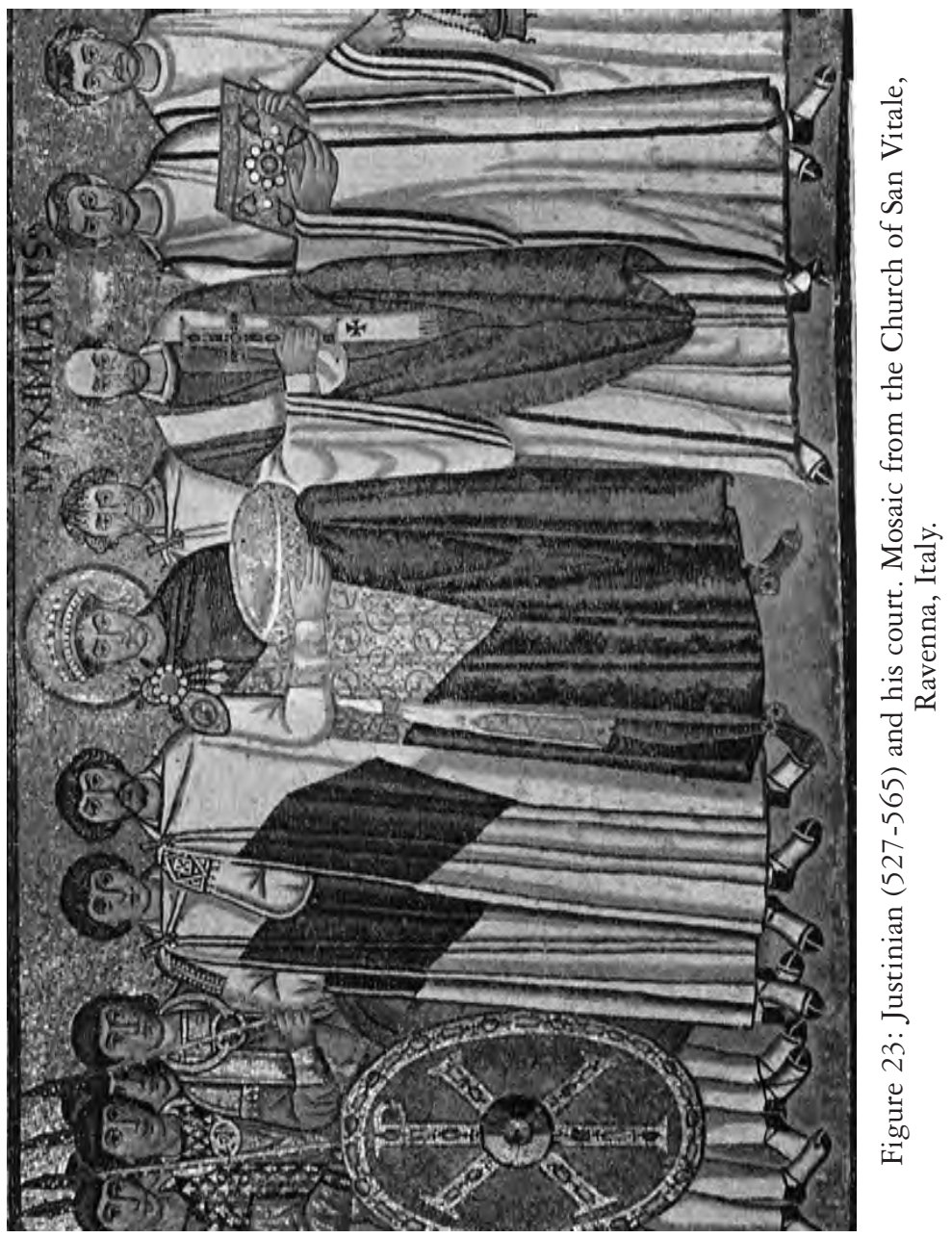


The epidemic of Justinian (542 AD)

\section{THE DISEASE}

\subsection{In Constantinople}

Procopius $^{2}$ reports that the epidemic first occurred in 540 in Pelusium, near the delta of the Nile in Egypt. Euagrius ${ }^{3}$ believes that it started in Ethiopia, but it must be borne in mind that the ancient authors thought almost all serious diseases had their origin in Ethiopia. From Egypt it spread to Palestine and beyond, reaching Constantinople in the spring of 542. It appears always to have spread from major ports to the interior, and does not seem to have followed any seasonal pattern. Procopius considered it to be a completely unknown disease, and an affliction sent from God. ${ }^{4}$ It gradually came to infect the whole known world, often by means of a recurrence of the epidemic in regions which had initially been only slightly affected, while communities which had been hard hit the first time were not usually severely afflicted again.

Procopius tells us that the Constantinople epidemic was characterised by disturbing omens. Before becoming ill, victims often (though not always) had visions or dreams of a supernatural being in human form (sometimes a headless black man) who would touch them, thus passing on the disease. Sometimes they simply heard voices. ${ }^{5}$ John of Ephesus $^{6}$ tells of visions of headless ghosts of black people rowing bronze boats with bronze oars at tremendous speed across the sea a frightening nocturnal sight due to the glimmering of the boats. These upsetting phenomena led people to lock their doors and refuse entry to all, out of fear of supernatural visitants.

The symptoms of the epidemic described by Procopius ${ }^{7}$ are basically similar to those noted by John of Ephesus. ${ }^{8}$ The disease presented with a sudden fever which was followed within one or more days by pain-

2 History II.22.6.

3 Ecclesiastical History IV.29.

4 History II.22.1; cf. also John of Ephesus, Commentary fr. II. E p. 228 lines 2236; II. F p. 229 line 30; II. G p. 233 lines 7-20; II. G p. 236 lines 12-18.

5 Procopius, History II.22.1.

6 Commentary fr.II E p. 229 lines 19-25.

7 History II.22.15-21 and 25-31.

8 Commentary fr.II G p. 234 lines 1-34. 
ful swellings (called bubos), particularly in the groin, but also in the armpits, the neck, the thighs, and elsewhere. Death could ensue at any time. Some patients developed a rash of black, pea-sized blisters, which was a sure prelude to death. Coma and delirium, restlessness, insomnia, and hallucinatory visions were common. Vomiting blood indicated imminent death. Some patients committed suicide by throwing themselves into rivers. For pregnant women, the disease was generally fatal. If a swelling burst and exuded pus, the patient usually recovered. Those who survived often suffered atrophy of the thighs or the tongue. Euagrius also mentions the following symptoms: initial headache, bloodshot eyes, sore throat and diarrhoea. ${ }^{9}$ This last symptom may be an indication of the very rare enteric plague. The other symptoms are explicable in terms of the unpredictable course of the disease, which Euagrius also mentions. ${ }^{10}$ In addition, Procopius notes ${ }^{11}$ that fever and swelling were general, but that the further course of the disease was characterised by a great diversity of symptoms.

Procopius also indicates that there was as much sympathy for those who had to nurse the victims as for the patients themselves because of the hard work involved. ${ }^{12}$ The care-givers were not considered to be at risk of contracting the plague by working among the victims, as it was found that neither doctors nor other caregivers contracted the plague from contact with patients or corpses, and many who busied themselves with burying or caring for non-related patients were able to continue with this service against all expectations, while many others would be overcome by the disease without any warning and would die almost instantly.

In Constantinople the epidemic lasted about four months in all, three of these being extremely severe. Doctors could discover no successful treatment. When the swellings on a few corpses were cut open, physicians found inflamed carbuncular tissue. It was apparent that the disease was not spread by direct contact. Even the emperor, Justinian, became ill with swellings in the groin, but he did not die. Procopius

9 Ecclesiastical History IV.29

10 Ibid. IV.29

11 History II.22.18

12 Ibid. II.22.23 
tells us that the mortality figure rose from 5000 to 10000 and more a day. ${ }^{13}$ According to John of Ephesus, the poor were particularly badly affected, with

first five, then seven, then twelve and ultimately up to sixteen thousand people dying on a single day, although the plague was only in its initial stages. ${ }^{14}$

All the available burial space was soon occupied and normal funeral arrangements were completely dislocated because corpses simply could not be dealt with. Later on, even the new graves on the outskirts of the city became fully occupied and a new mass graveyard was created for 70000 corpses in Galatia, across from the Bay of the Golden Horn. Corpses were also piled up in the hollow watchtowers of the Sycaean fortifications, which produced a terrible stench over the whole city. Others were loaded into boats which were allowed to drift away with the current. ${ }^{15}$ What made the greatest impression on John of Ephesus, in his capacity as a bishop, was the levelling effect of these deaths. $\mathrm{He}$ saw the epidemic as a lesson for sinful humanity: the piles of corpses on the beach included the rich and the poor, young people in the flower of their lives as well as grizzled old men, beggars along with prominent figures. ${ }^{16}$

All professional and business enterprises were suspended and schisms in families or groups were temporarily forgotten in combating the epidemic together. Constantinople came to a complete halt and the streets emptied. Severe famine broke out, increasing the death toll. Procopius tells us that many criminals gave up their illegal pursuits and began to assist in combating the crisis due to the fear of death, which threatened to strike at any time. Once the plague was over, however, those of them who survived immediately returned to their nefarious activities! ${ }^{17}$

The plague was to afflict Constantinople on four more occasions during Justinian's life. In 552 there was a severe epidemic among ani-

13 History II.23.2.

14 Commentary fr. II G p. 234, lines.1-10.

15 Procopius, History II.23.6-12.

16 Commentary fr.II H p. 235 lines 16-38 \& p. 236 lines 1-11.

17 Procopius, History II.23.13-16. 


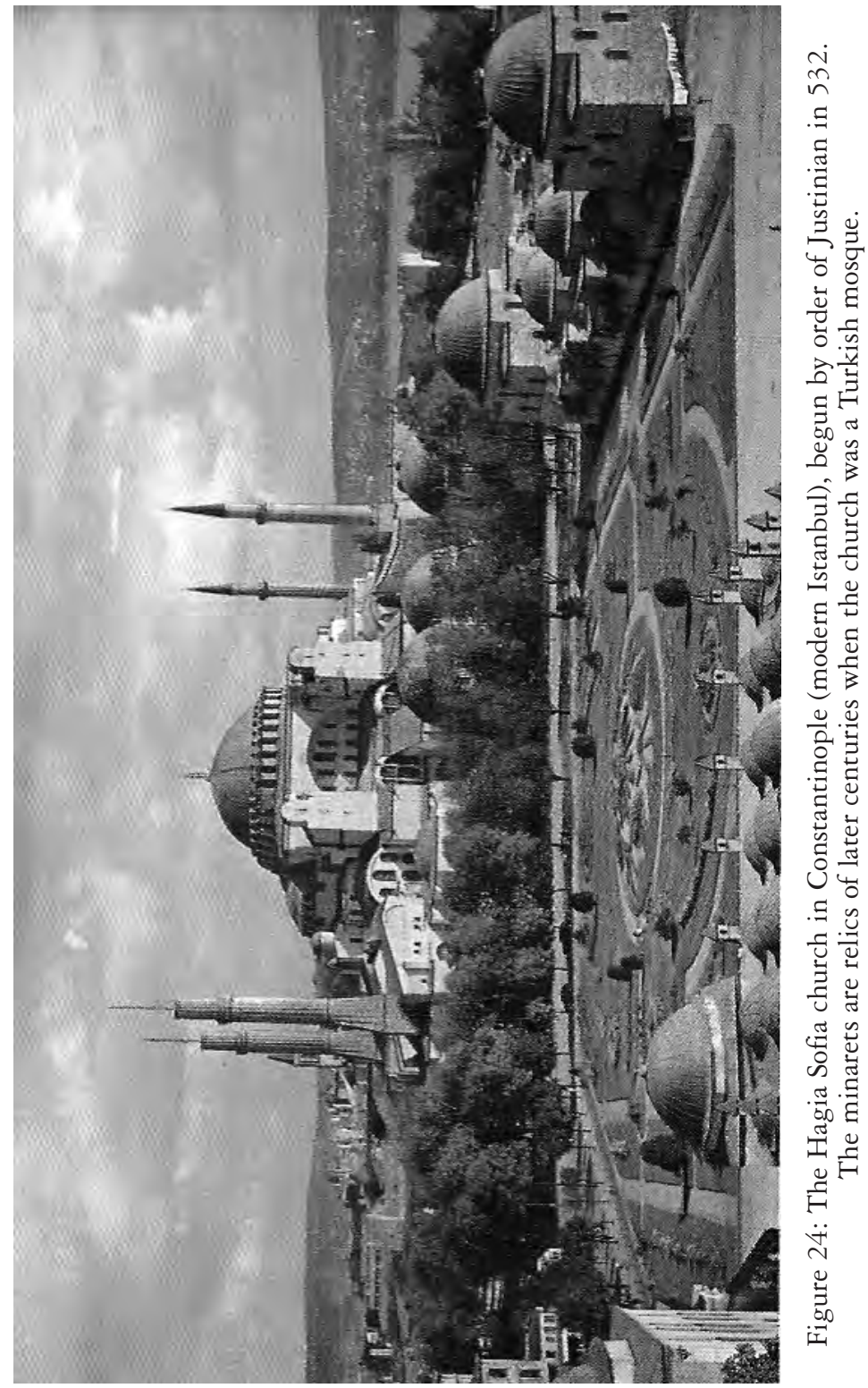


mals (including reptiles and mice) ${ }^{18}$ Further epidemics among human beings occurred in 553/4, 555/6 (when children were particularly affected $)^{19}$ and 558, when the plague was as devastating as that of 542 , although it affected more men than women.

After Justinian's death, epidemics struck the capital in 568/9, 570, $572 / 3,580 / 1,583 / 4$ and 585/6. According to Euagrius, ${ }^{20}$ the greatest loss of life would always occur in the second year of a plague. The $7^{\text {th }}$ century was relatively free of the plague until 687 and 697, when the final significant epidemics occurred.

\subsection{Elsewhere}

Later in the same year that it affected Constantinople, the pandemic broke out in Antioch and Syria. Euagrius, who had had bubonic plague as a child and wrote a moving description of the suffering of the community at Antioch, was later to lose his wife, several children and a grandchild to the plague. ${ }^{21}$ In 542 Persia was affected as well, and a whole regiment under the leadership of Chosroes I's son died of the disease. ${ }^{22}$ Allen (1979:14) refers to other local incidents including epidemics of the plague in Silesia, Anazarbus and Antioch in 560/1, recurring in Antioch in 592 and 598/9, after which it spread to Bithynia and Asia Minor. Alexandria suffered an epidemic in 612, and Egypt, Palestine and Syria in 598/60, Palestine again in 673 and Syria once more in $716 / 7$.

Early in its history the disease also spread beyond the Middle East, and Gaul (Arles and the Auvergne in particular) experienced epidemics of the plague in 551 and 582. Allen (1979:15) quotes Gregory of Tours's Historia Francorum, which describes an epidemic with a very high mortality figure occurring in 580 in Southern France. This probably included a high proportion of septicaemic plague (Allen 1979:13). In 588 Marseilles was afflicted with a plague which had spread from

18 John of Ephesus, Commentary fr.II B p. 234 lines 20-24.

19 Johannes Malalas, Chronographia p. 488; Theophanes Chronographia 6048. References from Allen (1979:13 n. 58).

20 Ecclesiastical History IV.29.

21 Ibid. IV.29.

22 Procopius, History II.24.8. 
Spain, and which recurred in 590/1. Avignon and Viviers were also affected, and in the same year Rome suffered an epidemic after serious flooding. In Thrace an Avarian army was wiped out by the plague. Tours and Nantes were afflicted in 591, and by about 634 the British Isles had also been infected. Over the next three decades the plague would have a major influence on the populations of England and Ireland. The disease also spread to the East, and McNeill (1976:134) notes epidemics of plague in China between 610 and 642. Since the disease tended to spread from the coast to the interior, it is believed to have been brought to China across the sea, two generations after it had broken out in the Middle East.

By the middle of the $8^{\text {th }}$ century the "plague of Justinian" had played itself out. In its endemic form, however, the disease was well established over an extensive area, and sporadic epidemics would break out from time to time up to the $20^{\text {th }}$ century, causing serious loss of life in many parts of the world.

\section{DISCUSSION}

\subsection{Clinical picture}

The syndrome described by Procopius is characteristic of the plague, and of bubonic plague in particular. Bubonic plague typically presents in its acute form with fever and within a few days the emergence of prominent, tender swellings of the lymph glands in any place on the body, but particularly in the groin, armpits, neck and thighs. The word "bubonic" is derived from the Greek word boubôn which means "groin" or "swollen gland" (often with specific reference to the groin). Coma and delirium are characteristic of the disease, and mortality figures for untreated cases are still high to this day (approximately 60$80 \%$ ), depending among other things on the patient's previous state of health. In pregnancy the mortality figure is very high, while atrophy of the thighs and tongue are well described as long-term complications. Suppuration of the bubos, with ulceration through the skin, has a good prognosis, as was indeed described by Procopius, but increases the risk of transmission. 
Bubonic plague is sometimes associated with early septicaemia when bubos are not necessarily prominent. This septicaemic plague has an even higher mortality rate and may also be associated with a vesicular eruption of the skin ("plague-pox"), as was described in Constantinople. Black skin vesicles would fit in with "haemorrhagic plague". Vomiting of blood may indicate enteric plague, with bleeding from the intestinal mucous membranes (a rare phenomenon) or pneumonic (lung) plague, with blood which has been coughed up and swallowed (Bratton 1980:2).

Untreated pneumonic plague is always fatal, and is associated with severe shortness of breath and coughing up blood. Unlike bubonic plague and the other variants mentioned above which are caused by the bite of infected fleas, pneumonic plague is contracted by means of direct infection from another patient with the disease. From Procopius's description, this plague does not appear to have featured significantly in 542 (Bratton 1980:2). A self-perpetuating epidemic of pneumonic plague would require a minimum population of 500 000, which Constantinople may well have had at the time, according to Allen (1979:11).

The omens described by both Procopius and John of Ephesus may have been hallucinations experienced by already feverish patients. Ziegler (1970:281) points out that similar phenomena were also reported during the "Black Death". On the other hand, a degree of theatrical historiography may equally well be involved here.

\subsection{Epidemiology}

The plague is a disease pertaining primarily to certain species of rodent. It presents as a mild disease in young animals (rather like endemic measles in human beings) and is spread by fleas. It can affect most species of rodent, including rats, which tolerate it poorly. Human contact usually occurs by means of bites from infected fleas which move from dead rats to human hosts. It is suspected that the plague organism Yersinia pestis originated in primitive times in symbiosis with subterranean rodent colonies in one of three areas of the world, viz. the Great Lakes area of Central Africa, the foothills of the Himalayas between India and China, and the Eurasian steppes between Manchuria and the Ukraine. Human infection almost certainly did not stem from 
the Eurasian area. Epidemics probably occurred mainly at times of migration of rodents (particularly the "black rats" from India) along with human beings from endemic areas to populated areas. Rats adapted well to the patterns of human life and have also been disseminated by marine travel since early times. The Byzantine plague could thus have come from Africa (via Ethiopia and Egypt) or from Asia (via trade routes). It is not certain when the rodent migrations began, but there is archaeological evidence that "black rats" (Rattus rattus) were present in the area of the Red Sea and in Macedonia (possibly even in Pompeii) during the early Christian era. The more aggressive Rattus norvegicus, which was to become the main carrier of the plague in the Middle Ages, only made its appearance in the $10^{\text {th }}$ century. As early as the $1^{\text {st }}$ century AD, Rufus of Ephesus described a disease which could have been bubonic plague, ${ }^{23}$ but the first clear description of the disease in its epidemic manifestation was the plague of Justinian. The Philistine "plague" of about $1000 \mathrm{BC}$ which is mentioned in the Bible (I Sam. 5:6) is sometimes cited as an example of bubonic plague (Wassermann 1997: $89,231)$, but accurate translations of the original texts render this diagnosis dubious (Shrewsbury 1964:13-39).

It is interesting that Procopius notes that the disease was not transmitted by direct personal contact, since this correlates well with bubonic plague (apparently the major variant of the epidemic of 542), which is spread by flea vectors. As has been mentioned, the vomiting of blood could indicate a small percentage of cases of pneumonic plague, which is directly transmitted by infected patients via droplets of moisture. Procopius also suggests that there was a degree of post-infective immunity to the disease, since communities which had been sorely afflicted were seldom seriously affected by later epidemics. ${ }^{24}$ It is known that immunity can be obtained by inoculation against the plague, although this is often only temporary in nature.

It would be difficult to calculate the mortality figures for the epidemic of 542. Bratton (1980:2) estimates Constantinople's population at 112500 (of which one-quarter died), but Allen (1979:11) thinks that it could have reached a maximum of 500000 at the time. Even then,

23 As given by Oribasius bk. III pp. 132.6-7.

24 History II.22.8. 
the mortality figures of 5000 to 16000 a day quoted by Procopius and John of Ephesus seem unacceptably high. The contention that the officials who were tasked with tallying the dead at the city gate gave up counting when they reached $230000^{25}$ must be a gross overstatement. More than $60 \%$ of all patients probably died, and the mortality figure was probably higher in Constantinople than in Alexandria or Antioch, or in the countryside, or among the semi-nomadic populations. Allen (1979:11) claims that, in all, about a third of the population died of the plague, a figure which would correlate with later European mortality rates at the time of the "Black Death".

\section{CONSEQUENCES}

The pandemic of 542 was a serious blow to Justinian, to the Eastern Roman Empire, and to nascent Europe. In Constantinople, economic decline and famine followed on the temporary collapse of agricultural activity. In 546 there was another shortage of grain and wine, and in May 556 (after a further epidemic) a three-month-long shortage of bread led to extensive rioting. In 560 it was rumoured that the emperor was dead, and once again serious "bread riots" followed. ${ }^{26}$

Justinian's eventual inability to reunite the area around the Mediterranean under Roman control, despite very effective military actions by Belisarius in particular, may be blamed largely on the enervating effects of the plague. The Middle Eastern population decreased significantly during this time, and Allen (1979:17) notes that the victories of the Persian military by the year 573 may be directly attributed to depopulation and debilitation of the Byzantine army. There is little doubt that the swift victories of the armies of Islam in the $7^{\text {th }}$ and $8^{\text {th }}$ centuries were also largely due to the destructive pandemic of Justinian. It may also be speculated that the demoralising and impoverishing influence of the plague delayed the development of Europe during a crucial phase after the demise of Graeco-Roman civilisation, thus precipitating the "Dark" period of the Middle Ages.

25 John of Ephesus, Commentary fr. G p. 234 1.9.

26 Johannes Malalas, Chronographia pp. 482 and 488; Theophanes Chronographia 6038, 6049 and 6053. References from Allen (1979:16 notes 84, 85 and 86). 


\section{REFERENCES}

\section{Allen P}

1979. The "Justinian plague". Byzantion 49:5-20.

\section{BAKKER E J}

1979. Procopius en de pest van Justinianus. Hermeneus 51(1):147-52.

\section{BRATTON T}

1980. The identity of the plague of Justinian according to Procopius. Society for Ancient Medicine Newsletter 7 (Oct):1-2.

\section{EUAGRIUS}

1964 (1898). The Ecclesiastical history of Euagrius with the scholia. (Eds. J. Bidex \& L. Parmentier.) Amsterdam: A.M. Hakkert.

\section{JOHN OF EPHESUS}

1889. Joannis Episcopi Ephesi Syri Monophysitae Commentarii de Beatis Orientalibus et Historiae Ecclesiasticae Fragmenta. Latin translation by W.J. van Douwen \& J.P.N. Land. (Transactions of the Royal Academy of the Netherlands, Literary Division 18.) Amsterdam: Müller.

\section{MCNeILL W H}

1976. Plagues and peoples. New York: Anchor Press.

\section{ORIBASIUS}

1964. Oribasii Collectionum Medicorum Reliquae. (Ed. I. Raeder.) Amsterdam: A.M. Hakkert.

\section{PROCOPIUS}

1979. History of the wars (transl. H.B. Dewing). London: W. Heinemann. Loeb Classical Library.

\section{SHREWSBURY J F D}

1964. The plague of the Philistines and other medico-historical essays. London: Victor Gollancz.

\section{WASSERMANN H P}

1997. Geneeskunde in die Bybel. Pretoria: J.L. van Schaik.

\section{ZIEGLER P}

1999. The Black Death. Edinburgh: St. Edmundsbury Press. 